\title{
Optimization of Gas-Water Absorption Equilibrium of Carbon Dioxide for Algae Liquors: Selection of Alkaline Buffering Chemicals
}

\author{
Wen-Hsi Cheng ${ }^{1}$ and Ming-Shean Chou ${ }^{2}$ \\ ${ }^{1}$ Department of Occupational Safety and Hygiene, Fooyin University, Kaohsiung City 83102, Taiwan \\ ${ }^{2}$ Institute of Environmental Engineering, National Sun Yat-Sen University, Kaohsiung City 80424, Taiwan \\ Correspondence should be addressed to Wen-Hsi Cheng; pl031@fy.edu.tw
}

Received 7 July 2016; Revised 20 October 2016; Accepted 24 October 2016

Academic Editor: Leonardo Palmisano

Copyright (C) 2016 W.-H. Cheng and M.-S. Chou. This is an open access article distributed under the Creative Commons Attribution License, which permits unrestricted use, distribution, and reproduction in any medium, provided the original work is properly cited.

\begin{abstract}
The apparent Henry's Law constant $\left(H^{\prime}\right)$, which quantifies the concentration partition of a gas-liquid equilibrium of carbon dioxide $\left(\mathrm{CO}_{2}\right)$, is used to optimize the absorption of carbon dioxide in algae liquors. The values of $H^{\prime}$ were examined under various conditions: in water at different temperatures $\left(27\right.$ and $\left.37^{\circ} \mathrm{C}\right)$, in alkaline buffering chemicals (sodium hydroxide $(\mathrm{NaOH})$ and sodium carbonate $\left(\mathrm{Na}_{2} \mathrm{CO}_{3}\right)$ ), and in aquatic algae plants (Egeria densa and Anubias barteri nana). The optimal conditions for $\mathrm{CO}_{2}$ absorption can be obtained by controlling the aqueous $\mathrm{pH}$ values (around weak alkalinity with $\mathrm{pH}$ 9-10) using sodium carbonate as an alkaline buffering chemical at $27^{\circ} \mathrm{C}$, yielding exact $H^{\prime}$ values of around $16.3-21.3 \mathrm{~atm} / \mathrm{M}$, which were obtained from the mean gaseous $\mathrm{CO}_{2}$ concentration of $803 \mathrm{ppm}$ and the total aqueous carbonate concentration of $4.085 \mathrm{mg} / \mathrm{L}$. The experimental results reveal that an alkaline buffering compound, sodium carbonate, can be added to water to maintain a constant aqueous alkalinity enough for the fixation of carbon dioxide by the photosynthesis of green algae in a photobioreactor.
\end{abstract}

\section{Introduction}

Carbon dioxide is the primary anthropogenic greenhouse gas, accounting for $77 \%$ of the human contribution to the greenhouse effect in recent decade [1]. Moreover, the exponential increase of carbon dioxide emissions into the atmosphere from the combustion of fossil fuels makes up the $86 \%$ of greenhouse gases [2]. The new generations of biofuels have been derived for their effective $\mathrm{CO}_{2}$ fixation, rapid growth rate, and high capacity to produce microalgae [3]. Photosynthesis has long been recognized as a means of capturing anthropogenic carbon dioxide. Aquatic microalgae are among the fastest growing photosynthetic organisms, with carbon fixation rates that are an order of magnitude greater than those of plants on land [4]. Camacho Rubio et al. reported [5] that the minimum of $2.4 \times 10^{-3} \mathrm{M}$ carbon dioxide (approximately $106 \mathrm{ppm}$ ) that yields a growth rate of $0.041 \mathrm{~h}^{-1}$ in cultures of Tetraselmis can be easily maintained in a tubular photobioreactor. However, microalgal photosynthesis by 24 tested strains is sustained when the microalgae are exposed to wide concentration ranges of carbon dioxide (5.7-100\%) in a flue gas [4]. Olaizola further used $\mathrm{pH}$ 6.5-8.5 in experiments with dissolved $\mathrm{CO}_{2}$ concentrations over 2 orders of magnitudes $(0.7-70 \mathrm{mg} / \mathrm{L})$ and found photochemical efficiencies close to the maximum. Olaizola concluded that as long as the $\mathrm{pH}$ in the algae system is controlled, no deleterious effects on photochemical efficiency occur for various aqueous $\mathrm{CO}_{2}$ contents [4]. Controlling $\mathrm{pH}$ in an algae system is critical for the photochemical process.

It has been developed that new solvents such as aqueous amine and piperazine promoted $\mathrm{K}_{2} \mathrm{CO}_{3}$ were applied to increase the aqueous absorption capacity of $\mathrm{CO}_{2}$ from the flue gas [6-8]. Cullinane and Rochelle [9] measured $\mathrm{CO}_{2}$ solubility in a wetted-wall column in $0.6-3.6 \mathrm{~mole} / \mathrm{L}$ piperazine and 2.5-6.2 mole/L potassium ion at a high temperature range of $40-110^{\circ} \mathrm{C}$. Rahimpour and Kashkooli [10] also simulated $\mathrm{CO}_{2}$ solubility along with aqueous potassium ion at a high temperature range of $50-130^{\circ} \mathrm{C}$. The presence of potassium 
in solution increases the concentration of $\mathrm{CO}_{3}{ }^{2-} / \mathrm{HCO}_{3}{ }^{-}$in solution. Generally, the temperatures of industrial flue gas streams are lower than those for process $\mathrm{CO}_{2}$ recovery [11]. Since studies of controlling aqueous $\mathrm{pH}$ in the air/algae water $\mathrm{CO}_{2}$ system are few, in this work, various alkaline buffering compounds (sodium hydroxide and sodium carbonate) were added to water to keep its $\mathrm{pH}$ constant for the ordinary ambient temperatures (around $27-37^{\circ} \mathrm{C}$ ). The apparent Henry's Law constant, which specifies the concentration partitioning relationships at the gas-liquid equilibrium for carbon dioxide, is used.

\section{Method}

2.1. Theory. Equations (1) and (2) describe the gas-liquid equilibrium for a carbonic system:

$$
\begin{aligned}
& \mathrm{CO}_{2(\mathrm{~g})}+\mathrm{H}_{2} \mathrm{O} \longrightarrow \mathrm{CO}_{2(\mathrm{aq})}+\mathrm{H}_{2} \mathrm{O} \longrightarrow \mathrm{H}_{2} \mathrm{CO}_{3(\mathrm{aq})} \\
& H^{\prime}
\end{aligned}
$$

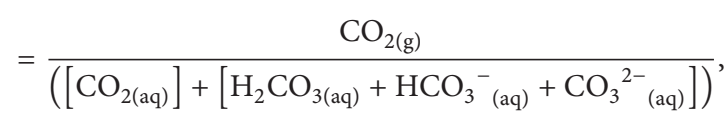

where $H^{\prime}$ is the apparent Henry's Law constant for the gasliquid equilibrium of carbon dioxide. Generally, atmospheric and aqueous carbon dioxide is regarded as a closed system [12]; meaning that the mass exchange rate of carbon dioxide between the gas and liquid phases is much less than the reaction rate of carbon dioxide in water [12]. Equations (3) and (4) present main reactions of carbon dioxide in water:

$$
\begin{aligned}
& \mathrm{H}_{2} \mathrm{CO}_{3(\mathrm{aq})} \stackrel{K_{1}}{\longleftrightarrow} \mathrm{H}^{+}{ }_{(\mathrm{aq})}+\mathrm{HCO}_{3}{ }_{(\mathrm{aq})} \\
& \mathrm{HCO}_{3}{ }_{(\mathrm{aq})} \stackrel{K_{2}}{\longleftrightarrow} \mathrm{H}^{+}{ }_{(\mathrm{aq})}+\mathrm{CO}_{3}{ }^{2-} \text { (aq) }
\end{aligned}
$$

The total concentration of both diluted carbon dioxide and carbonate is denoted as a new concentration term, $\mathrm{H}_{2} \mathrm{CO}_{3}{ }^{*}$, and $\mathrm{C}_{T}$ is the total concentration of aqueous carbonic species. Equation (5) is thus obtained as follows:

$$
C_{T}=\left[\mathrm{H}_{2} \mathrm{CO}_{3}{ }^{*}\right]+\left[\mathrm{HCO}_{3}{ }^{-}\right]+\left[\mathrm{CO}_{3}{ }^{2-}\right] .
$$

Combining (2)-(5) yields the apparent Henry's Law constant $\left(H^{\prime}\right)$ for atmospheric carbon dioxide $\left(\mathrm{CO}_{2(\mathrm{~g})}\right)$ and $C_{T}$ in

$$
\begin{aligned}
H^{\prime} & =\frac{\left[\mathrm{CO}_{2(\mathrm{~g})}\right]}{C_{T}} \\
& =\frac{\left[\mathrm{CO}_{2(\mathrm{~g})}\right]}{\left[\mathrm{H}_{2} \mathrm{CO}_{3}{ }^{*}\right]\left[1+K_{1}^{\prime} /\left[\mathrm{H}^{+}\right]+K_{1}^{\prime} K_{2}^{\prime} /\left[\mathrm{H}^{+}\right]^{2}\right]},
\end{aligned}
$$

where $K_{1}^{\prime}$ and $K_{2}^{\prime}$ are ionization constants of carbonate and bicarbonate. According to Benefield et al. [12], at $25^{\circ} \mathrm{C}$, dimensionless $K_{1}=4.2 \times 10^{-7}$ and $K_{2}=4.8 \times 10^{-11}$. The corrected values of $K_{1}$ and $K_{2}$ at $27^{\circ} \mathrm{C}$ are $4.3 \times 10^{-7}$ and $5.8 \times 10^{-11}$ and at $37^{\circ} \mathrm{C}$ are $4.7 \times 10^{-7}$ and $6.1 \times 10^{-11}$, respectively.
Theoretically, the value of $H^{\prime}$ for aqueous carbon dioxide is influenced by the temperature of water and other contents (i.e., $\mathrm{pH}$ and total dissolved solids (TDS)) [12]. Pure water that is produced using a reverse osmosis (RO) system was used as the absorption liquor, so the effect of TDS on $H^{\prime}$ can be neglected. The Results and Discussion will elucidate the effect of temperature on $H^{\prime}$.

Gas-liquid $\mathrm{CO}_{2}$ simulated data (Figure 2) was shown to study the effect of buffering materials $\mathrm{NaOH}$ and $\mathrm{Na}_{2} \mathrm{CO}_{3}$ on the values of $H^{\prime}$ in algal liquor. A total organic carbon/total inorganic carbon (TOC/TIC) analyzer was used to obtain aqueous TIC content, represented as $C_{T}$ (mole/L) [13]. Simultaneously, the partial pressure (atm) of gaseous $\mathrm{CO}_{2}$ in the headspace of the closed gas-liquid system is continuously analyzed using a $\mathrm{CO}_{2}$ analyzer [14]. The calculated $H^{\prime}$ values can be compared to the estimated $H^{\prime}$ for various buffering materials in water, and the optimal aqueous absorption conditions of carbon dioxide can thus be obtained.

2.2. Experiment. The experiment herein was performed in three phases. In Phase I, the values of $H^{\prime}$ at the water temperatures 27 and $37^{\circ} \mathrm{C}$ for the absorption of $600-2000 \mathrm{ppm}$ $\mathrm{CO}_{2}$ neutral absorption water $(\mathrm{pH} \approx 7)$ were compared. In Phase II, two buffering agents, $\mathrm{NaOH}$ and $\mathrm{Na}_{2} \mathrm{CO}_{3}$, were used to adjust the $\mathrm{pH}$ of the absorbent liquor around 6.5-10. In Phase III, two species of green algae were placed in the water to absorb $\mathrm{CO}_{2}$. The effects of deviations of $\mathrm{pH}$ on values of $H^{\prime}$ of $\mathrm{CO}_{2}$ during Phases I-III were observed.

2.3. Apparatus and Materials. A temperature-controlled oven (HIPOINT, 721, Taiwan) of interior volume 150-L, connected to a 0.25 - Hp chilling system of controllable temperature range of $0-80^{\circ} \mathrm{C}\left( \pm 0.02^{\circ} \mathrm{C}\right)$, was used. A stainless steel constant temperature basin (HIPOINT, Taiwan), which uses an LED thermal controller, provided water at a constant temperature. The visible light source to promote algal growth was fluorescent lamps (Mr. Aqua, Taiwan) with a total power of $13 \mathrm{~W}$. An air agitator, connected to a flow rate regulator, provided $20 \mathrm{~L} \mathrm{CO}_{2}$ per min to the $\mathrm{CO}_{2}$ aeration reactor (Figure 1). A metering pump (EYELA MP-1000H, Japan, Figure 1) transferred $\mathrm{CO}_{2}$ enriched water at $50 \mathrm{~mL} / \mathrm{min}$ into and out of a closed Erlenmeyer flask. The $\mathrm{CO}_{2}$ equilibrium between air and water was established inside the Erlenmeyer flask. The variations of $\mathrm{CO}_{2}$ concentration over time were examined using a $\mathrm{CO}_{2}$ detector with a nondispersive infrared (NDIR) sensor (MultiRAE PGM-54, USA), which could detect 0-20,000 $\mathrm{ppm} \mathrm{CO}_{2}$, and had a resolution and response time of $10 \mathrm{ppm}$ and $60 \mathrm{~s}$, respectively. Aqueous TIC was investigated using a TIC/TOC analyzer (SHIMADZU, TOCVCPH, serial number H51304400704AE, Japan). Aqueous acidity/alkalinity values were obtained using a $\mathrm{pH}$ meter (WTW, Germany) with a $\mathrm{pH}$ detection range from -2.00 to 16.00 and $\mathrm{pH}$ resolution of 0.01 .

Plastic syringes with a volume of $10 \mathrm{~mL}$ were used to extract water samples. Pure water was provided using a Millipore reverse osmosis (RO) system (RiOs-3/MilliQ, USA). According to Serebryakova et al.s experimental design [15], gaseous $\mathrm{CO}_{2}$ was provided using a steel cylinder with a purity of more than 99\%. All chemicals (sodium 


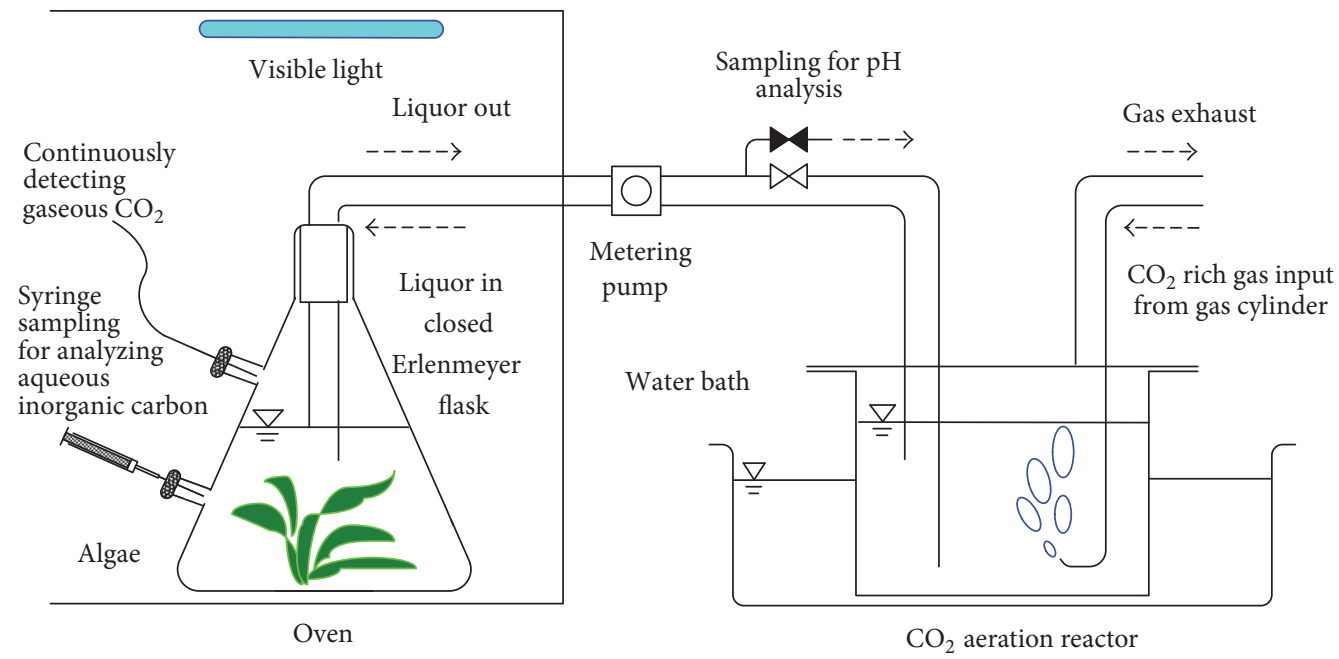

FIGURE 1: Experimental setup for carbon dioxide gas/liquor partitioning equilibrium.

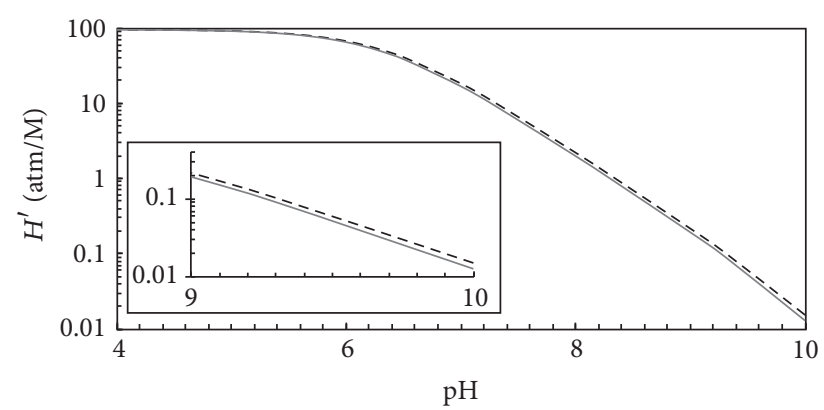

FIgURE 2: Variations of apparent Henry's Law constants with $\mathrm{pH}$ and temperature for $\mathrm{CO}_{2(\mathrm{~g})}=1500 \mathrm{ppm}$ and $\mathrm{H}_{2} \mathrm{CO}_{3}{ }^{*}=1.5 \mathrm{mg} / \mathrm{L}$ (solid line indicates $25^{\circ} \mathrm{C}$ and dash line indicates $35^{\circ} \mathrm{C}$ ).

hydroxide and sodium carbonate) were analytical grades. Two green algae, Egeria densa and Anubias barteri nana, which were approximately $10 \mathrm{~cm}$ tall, were purchased from a local aquarium.

\section{Results and Discussion}

\subsection{Variation of Apparent Henry's Law Constants with pH Values}

3.1.1. Theoretical Calculation. Setting $\mathrm{CO}_{2}=1,500 \mathrm{ppm}$ and $\mathrm{H}_{2} \mathrm{CO}_{3}{ }^{*}=1.5 \mathrm{mg} / \mathrm{L}$ in (6) yields the variations of $H^{\prime}$ with $\mathrm{pH}$ at water temperature of 27 and $37^{\circ} \mathrm{C}$, which are plotted in Figure 2. When the alkaline liquor (with a $\mathrm{pH}$ value of more than 8) absorbs $1,500 \mathrm{ppm} \mathrm{CO}_{2}$, the $H^{\prime}$ values will be as low as $2.2 \mathrm{~atm} / \mathrm{M}$ because of the high concentration of aqueous carbonate species, which absorb much gaseous carbon dioxide. As the $\mathrm{pH}$ value rises, the $H^{\prime}$ value increases; for example, at a $\mathrm{pH}$ in the range from 8 to 6 , the $H^{\prime}$ value increases from $2.2 \mathrm{~atm} / \mathrm{M}$ to $65 \mathrm{~atm} / \mathrm{M}$, so the $\mathrm{CO}_{2}$ absorption capacity gradually falls as the $\mathrm{pH}$ value of the water decreases. Figure 2 further reveals that if the $\mathrm{pH}$ is

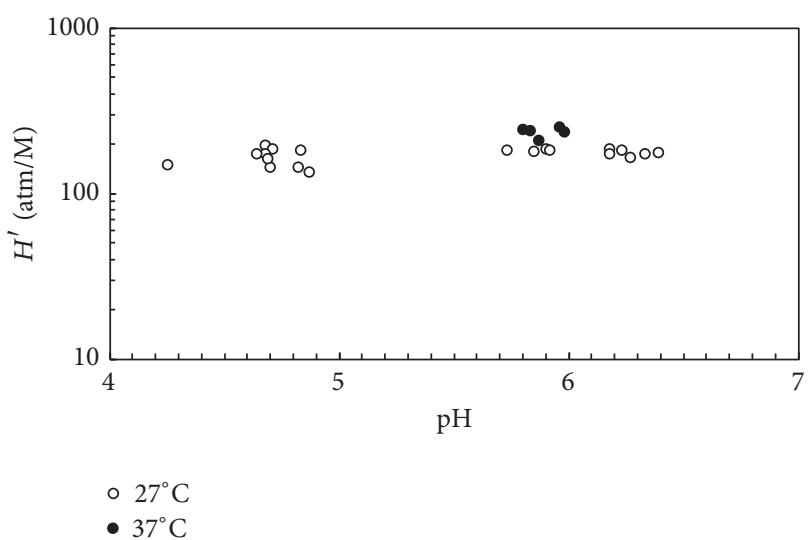

FIGURE 3: Variations of apparent Henry's Law constants with $\mathrm{pH}$ at different water temperatures.

between 4 and 5 , then $H^{\prime}$ is almost in the range $90-94 \mathrm{~atm} / \mathrm{M}$, and the acidic liquor absorbs limited amount of carbon dioxide.

The $H^{\prime}$ values at $35^{\circ} \mathrm{C}$ and $25^{\circ} \mathrm{C}$ differ considerately only at $\mathrm{pH}$ values higher than 9 (Figure 2). The calculated $H^{\prime}$ is $0.22 \mathrm{~atm} / \mathrm{M}$ at $35^{\circ} \mathrm{C}$ and $0.19 \mathrm{~atm} / \mathrm{M}$ at $25^{\circ} \mathrm{C}$ at $\mathrm{pH}$ 9. The effect of temperature on the $\mathrm{CO}_{2}$ gas-liquor partitioning equilibrium is much weaker than that of aqueous acidity/alkalinity.

3.1.2. Effect of Temperature on $\mathrm{CO}_{2}$ Gas-Liquor Equilibrium in Pure Water. According to Figure $3, C_{T}=0.87 \pm 0.51 \mathrm{mg} / \mathrm{L}$ (which is slightly lower than the simulated concentration, $1.5 \mathrm{mg} / \mathrm{L}$ ) for $\mathrm{pH} 4-7$; at $27^{\circ} \mathrm{C}$, the mean value of $H^{\prime}$ is $171.3 \mathrm{~atm} / \mathrm{M}$ and the standard deviation is $16.8 \mathrm{~atm} / \mathrm{M}$, and at $37^{\circ} \mathrm{C}$, the mean value of $H^{\prime}$ is $235.4 \mathrm{~atm} / \mathrm{M}$ and the standard deviation is $30.8 \mathrm{~atm} / \mathrm{M}$. Therefore, $H^{\prime}$ and its deviations at high and low temperature reveal that the $\mathrm{CO}_{2}$ gas-liquor equilibrium is less steady state in hot water than in cool water.

When the aqueous alkalinity at $27^{\circ} \mathrm{C}$ was not controlled, the $\mathrm{pH}$ did not fall to 7.0 or less, and $H^{\prime}$ remained in the high 


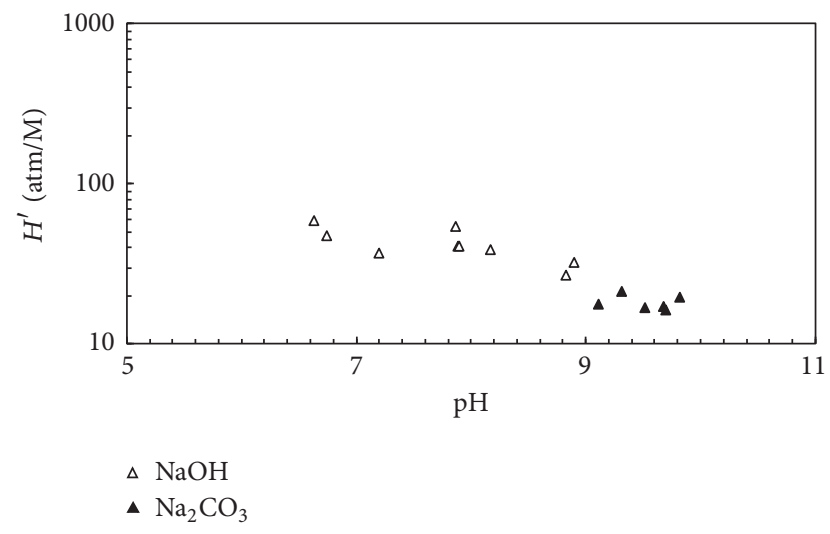

Figure 4: Variations of apparent Henry's Law constants with pH (at $27^{\circ} \mathrm{C}$ ) for adding different alkaline buffering materials.

range of $134-185 \mathrm{~atm} / \mathrm{M}$. The values of $C_{T}$ were as low as $0.87 \pm$ $0.51 \mathrm{mg} / \mathrm{L}$, so alkaline chemicals had to be added to increase the buffer capacity and dissolve more $\mathrm{CO}_{2}$ into the water.

3.2. Effect of Alkaline Chemicals on $\mathrm{CO}_{2}$ Partition Equilibrium. The experimental results (Figure 4) reveal that when the initial $\mathrm{pH}$ value of pure water ranged from 9.98 to 10.31 and the $\mathrm{CO}_{2}$ aeration period was $2.5 \mathrm{~h}$, use of $\mathrm{NaOH}$ as an alkaline buffer yields aqueous $\mathrm{pH}$ values in the range 6.6-8.9, which were much lower than the $\mathrm{pH}$ values (9.1-9.8) obtained using $\mathrm{Na}_{2} \mathrm{CO}_{3}$ as a buffer. Adding $\mathrm{Na}_{2} \mathrm{CO}_{3}$ yielded $H^{\prime}$ values in the range $16.3-21.3 \mathrm{~atm} / \mathrm{Mm}$ whereas adding $\mathrm{NaOH}$ yielded $H^{\prime}$ values in the range 27.0-59.5 atm/M. Adding $\mathrm{Na}_{2} \mathrm{CO}_{3}$ yielded a mean gaseous $\mathrm{CO}_{2}$ concentration of $803 \mathrm{ppm}$ (with a standard deviation of $248 \mathrm{ppm}$ ) and adding $\mathrm{NaOH}$ yielded a mean gaseous $\mathrm{CO}_{2}$ concentration of $1,236 \mathrm{ppm}$ (with a standard deviation of $560 \mathrm{ppm}$ ). Briefly, the weak alkali, $\mathrm{Na}_{2} \mathrm{CO}_{3}$, had a greater acidity/alkalinity buffering capacity than the strong alkali $\mathrm{NaOH}$.

3.3. Effect of Algae Plants on $\mathrm{CO}_{2}$ Partition Equilibrium. In this phase, two green algal plants, Egeria densa and Anubias barteri nana, were seeded in the water to which $\mathrm{Na}_{2} \mathrm{CO}_{3}$ was subsequently added. The gas-liquor $\mathrm{CO}_{2}$ partition equilibrium was then observed. According to Figure 5, the $H^{\prime}$ values in the water with algae were higher than those in water without algae: the $H^{\prime}$ value was increased by the reduction of aqueous hydrocarbonate concentration. Therefore, algae are inferred to use visible light as an energy source and aqueous hydrocarbonate as a carbon source for photosynthesis. The $H^{\prime}$ values obtained with Anubias barteri nana were higher than those obtained with Egeria densa, preliminarily indicating that the aqueous hydrocarbonate assimilation efficiency of Anubias barteri nana is higher than that of Egeria densa.

\section{Conclusions}

This work concerned the gas/water partitioning equilibrium of carbon dioxide under various conditions of water temperatures $\left(27\right.$ and $\left.37^{\circ} \mathrm{C}\right)$, alkaline buffers $(\mathrm{NaOH}$ and

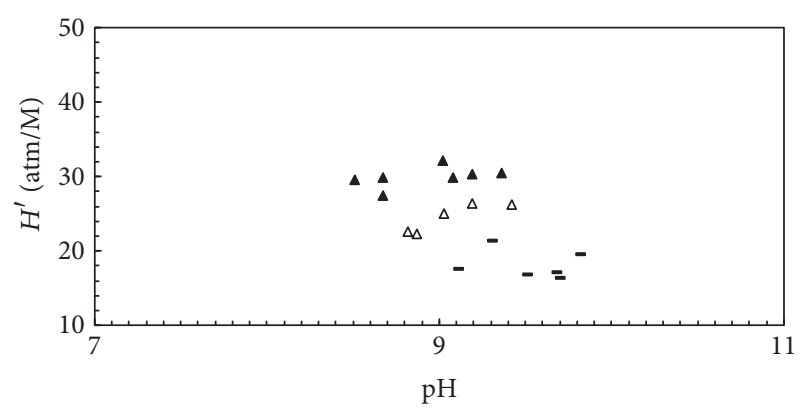

- Anubias barteri var. nana

$\triangle$ Egeria densa

- No algae

FIGURE 5: Variations of apparent Henry's Law constants with pH (at $27^{\circ} \mathrm{C}$ ) for seeding different algae plants.

$\mathrm{Na}_{2} \mathrm{CO}_{3}$ ), and aquatic algae plants (Egeria densa and Anubias barteri nana). The optimal conditions for $\mathrm{CO}_{2}$ absorption are obtained by maintaining a weakly alkaline aqueous $\mathrm{pH}$ of 910 by adding $\mathrm{Na}_{2} \mathrm{CO}_{3}$ as an alkalinity buffering chemical at $27^{\circ} \mathrm{C} ; H^{\prime}$ values were in the range $16.3-21.3 \mathrm{~atm} / \mathrm{M}$, which were obtained from mean gaseous $\mathrm{CO}_{2}$ and aqueous $\mathrm{H}_{2} \mathrm{CO}_{3}{ }^{*}$ concentration of $803 \mathrm{ppm}$ and $4.085 \mathrm{mg} / \mathrm{L}$, respectively.

The reduction of acidity for the carbon dioxide fixation using aquatic algae is critical to maintaining the absorption efficiency of carbon dioxide in water, and the addition of alkaline buffering chemicals seems to be a feasible means. In this work, aquatic algae plants (Egeria densa and Anubias barteri nana) were grown in carbon-dioxide-aerated and $\mathrm{H}_{2} \mathrm{CO}_{3}{ }^{*}$-conditioned water, in which the mean aqueous $\mathrm{H}_{2} \mathrm{CO}_{3}{ }^{*}$ concentration was $2.464 \mathrm{mg} / \mathrm{L}$ and the gaseous $\mathrm{CO}_{2}$ concentration was $749 \mathrm{ppm}$.

\section{Competing Interests}

All authors declare they have no competing interests.

\section{Acknowledgments}

The authors would like to thank the Ministration of Science and Technology of the Republic of China, Taiwan, for financially supporting this research under Contract no. NSC 96-EPA-Z-110-001.

\section{References}

[1] E. Torralba-Calleja, J. Skinner, and D. Gutiérrez-Tauste, " $\mathrm{CO}_{2}$ capture in ionic liquids: a review of solubilities and experimental methods," Journal of Chemistry, vol. 2013, Article ID 473584, 16 pages, 2013.

[2] M. Songolzadeh, M. Soleimani, M. T. Ravanchi, and R. Songolzadeh, "Carbon dioxide separation from flue gases: a technological review emphasizing reduction in greenhouse gas emissions," The Scientific World Journal, vol. 2014, Article ID 828131, 34 pages, 2014.

[3] C. P. Joshi and A. Nookaraju, "New avenues of bioenergy production from plants: green alternatives to petroleum," Journal 
of Petroleum \& Environmental Biotechnology, vol. 3, article 134, 2012.

[4] M. Olaizola, "Microalgal removal of $\mathrm{CO}_{2}$ from flue gases: changes in medium $\mathrm{pH}$ and flue gas composition do not appear to affect the photochemical yield of microalgal cultures," Biotechnology and Bioprocess Engineering, vol. 8, no. 6, pp. 360367, 2003.

[5] F. Camacho Rubio, F. G. Acién Fernández, J. A. Sánchez Pérez, F. García Camacho, and E. Molina Grima, "Prediction of dissolved oxygen and carbon dioxide concentration profiles in tubular photobioreactors for microalgal culture," Biotechnology and Bioengineering, vol. 62, no. 1, pp. 71-86, 1999.

[6] M. Takht Ravanchi and S. Sahebdelfar, "Carbon dioxide capture and utilization in petrochemical industry: potentials and challenges," Applied Petrochemical Research, vol. 4, no. 1, pp. 63-77, 2014.

[7] Y. Li, Y. Liu, H. Zhang, and W. Liu, "Carbon dioxide capture technology," Energy Procedia, vol. 11, pp. 2508-2515, 2011.

[8] J. A. Delgado, M. A. Uguina, J. L. Sotelo, V. I. Águeda, and A. Sanz, "Simulation of $\mathrm{CO}_{2}$ absorption into aqueous DEA using a hollow fiber membrane contactor: evaluation of contactor performance," Chemical Engineering Journal, vol. 152, no. 2-3, pp. 396-405, 2009.

[9] J. T. Cullinane and G. T. Rochelle, "Thermodynamics of aqueous potassium carbonate, piperazine, and carbon dioxide," Fluid Phase Equilibria, vol. 227, no. 2, pp. 197-213, 2005.

[10] M. R. Rahimpour and A. Z. Kashkooli, "Enhanced carbon dioxide removal by promoted hot potassium carbonate in a split-flow absorber," Chemical Engineering and Processing: Process Intensification, vol. 43, no. 7, pp. 857-865, 2004.

[11] P. H. M. Feron and A. E. Jansen, " $\mathrm{CO}_{2}$ separation with polyolefin membrane contactors and dedicated absorption liquids: performances and prospects," Separation and Purification Technology, vol. 27, no. 3, pp. 231-242, 2002.

[12] L. D. Benefield, J. F. Judkins, and B. L. Weand, Weand, PrenticeHall, Englewood Cliffs, NJ, USA, 1982.

[13] American Public Health Association, American Water Works Association, and Water Pollution Control Federation, Standard Methods for the Examination of Water and Wastewater, Method 5310C, American Public Health Association, American Water Works Association \& Water Pollution Control Federation, Washington, DC, USA, 20th edition, 1998.

[14] U.S. EPA, Compendium of methods for the determination of air pollutants in indoor air, Method IP-3, 1990.

[15] L. Serebryakova, N. Novichkova, and I. Gogotov, "Facultative $\mathrm{H} 2$-dependent anoxygenic photosynthesis in the unicellular cyanobacterium Gloeocapsa alpicola CALU 743," International Journal of Photoenergy, vol. 4, no. 4, pp. 169-173, 2002. 

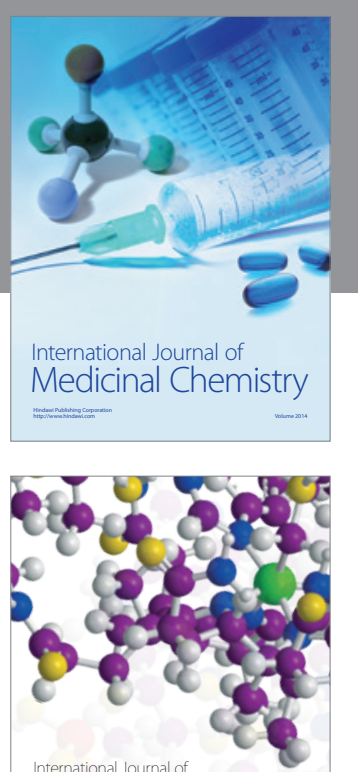

Carbohydrate Chemistry

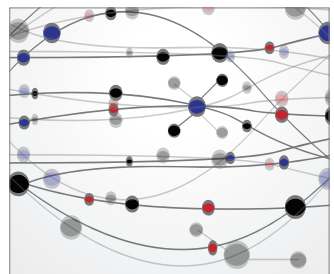

The Scientific World Journal
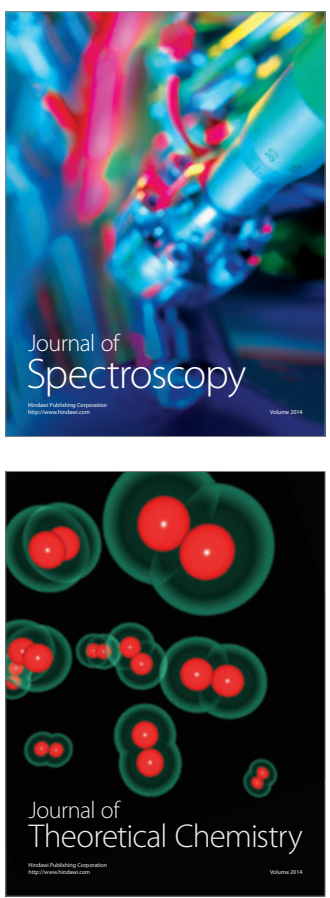
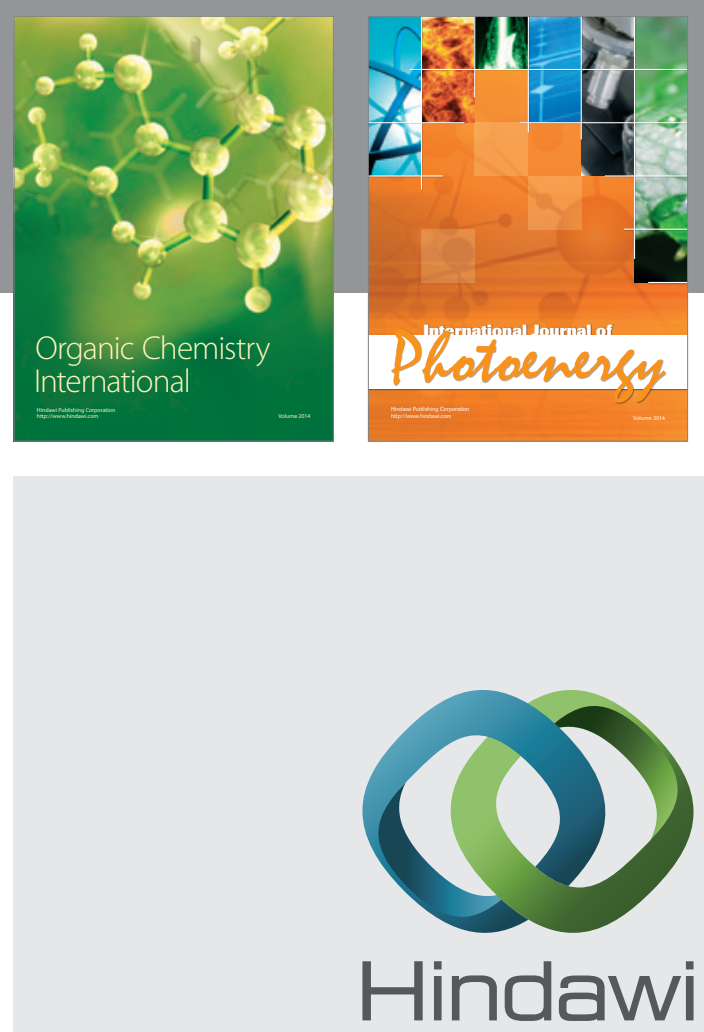

Submit your manuscripts at

http://www.hindawi.com

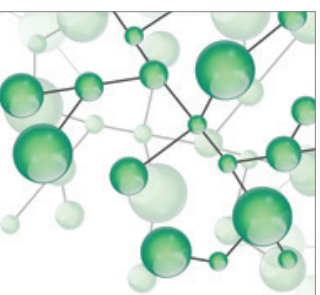

International Journal of

Inorganic Chemistry

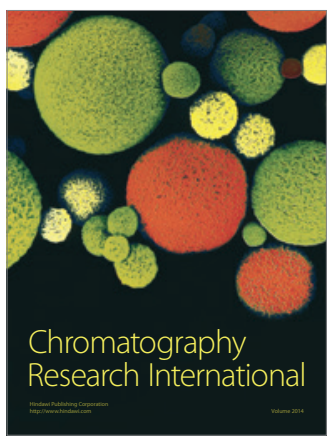

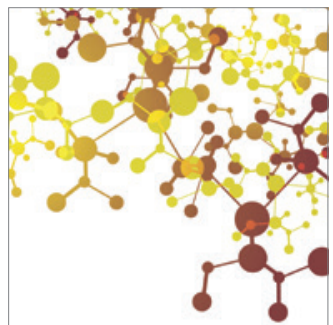

Applied Chemistry
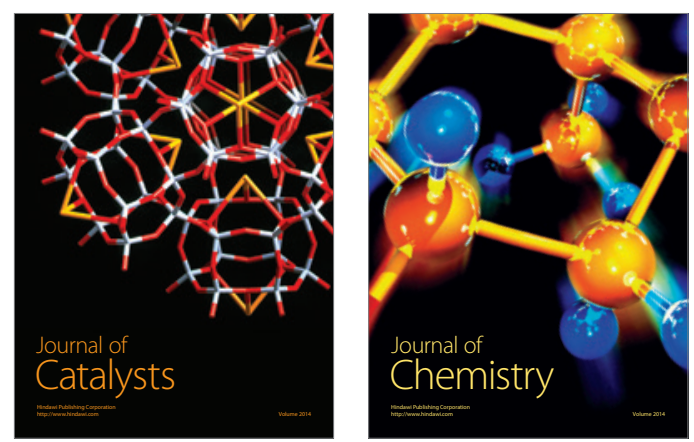
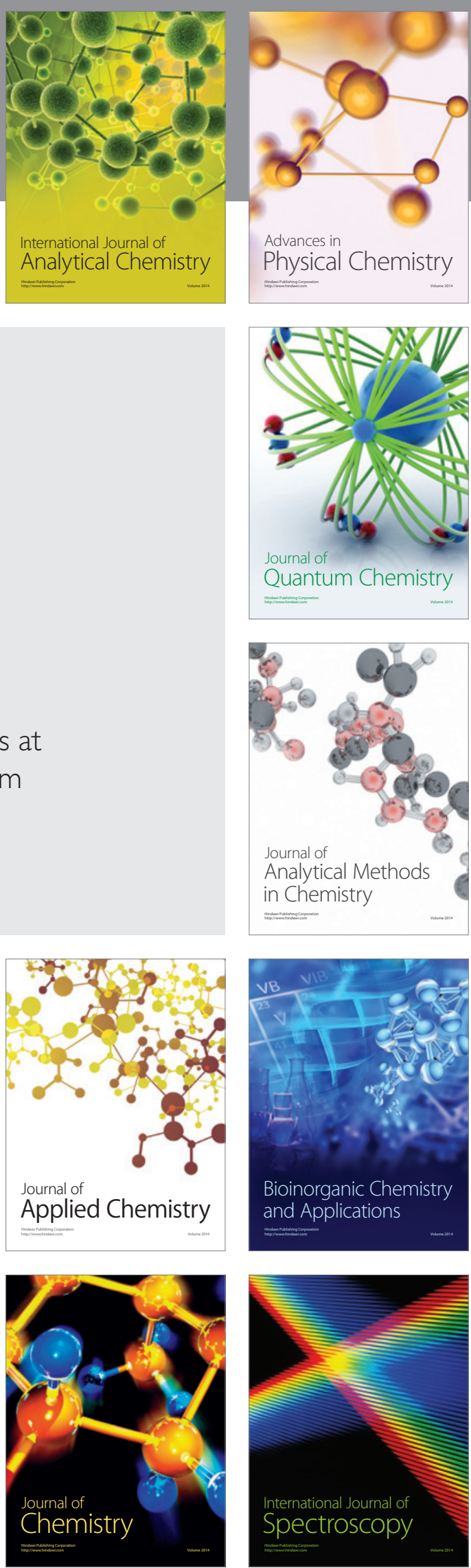